\title{
Role of positron emission tomography-computed tomography in bronchial mucoepidermoid carcinomas: a case series and review of the literature
}

Tarun Jindal ${ }^{1}$, Arvind Kumar ${ }^{1 *}$, Rakesh Kumar², Roman Dutta ${ }^{1}$, Monika Meena ${ }^{1}$

\begin{abstract}
Introduction: Mucoepidermoid carcinoma of the tracheobronchial tree is rare. Such tumors usually present with signs and symptoms of bronchial obstruction. Histologically, they can be classified as high-grade or low-grade tumors. Experience of imaging these tumors with ${ }^{18}$ fluorodeoxyglucose positron emission tomography-computed tomography $\left({ }^{18} \mathrm{~F}-\mathrm{FDG}\right.$ PET-CT) is limited. We present three cases of this rare tumor, describe the functional imaging results, and review the available literature.
\end{abstract}

Case presentation: Three Caucasian patients, two men (21 and 24 years of age) and one woman (14 years of age), with bronchial masses were evaluated by us. All three patients were symptomatic, and underwent a thorough clinical examination, bronchoscopy and biopsy, plain computed tomography, ${ }^{18}$ F-FDG PET-CT and ${ }^{68}$ Gallium 1,4,7,10-Tetraazacyclododecane- $N^{\prime}, N^{\prime \prime}, N^{\prime \prime \prime}, N^{\prime \prime \prime \prime I},-$ tetra acetic acid (D) - Phel ${ }^{1}$-Tyr ${ }^{3}$-octreotide positron emission tomography-computed tomography $\left({ }^{68} \mathrm{Ga}\right.$-DOTATOC PET-CT). ${ }^{18}$ F-FDG PET-CT revealed mild uptake in all three patients, whereas ${ }^{68} \mathrm{Ga}$-DOTATOC PET-CT revealed no significant uptake in any patient, making carcinoid tumor unlikely. Results of histopathological examination were consistent with low-grade mucoepidermoid carcinoma in all patients.

Conclusion: Our study reveals that functional imaging may be helpful in the initial investigation of patients with mucoepidermoid carcinoma. ${ }^{18}$ F-FDG PET-CT may have a prognostic relevance by predicting the histopathologic differentiation of the tumor.

\section{Introduction}

Mucoepidermoid carcinoma (MEC) of the trachealbronchial tree is rare, comprising only $0.1 \%$ to $0.2 \%$ of primary lung malignancies [1]. It is believed to originate from the minor salivary glands lining the tracheal-bronchial tree. Although considered an indolent tumor, local invasion and lymph node metastases may occur. Computed tomography (CT) usually reveals a solitary nodule or an endobronchial mass with or without post-obstructive pneumonia or atelectasis [2]. Recently, ${ }^{18}$ fluorodeoxyglucose $\left({ }^{18} \mathrm{~F}-\mathrm{FDG}\right)$ positron emission tomography (PET)-CT has been reported to be useful in lung

\footnotetext{
* Correspondence: arvindreena@gmail.com

'Department of Surgical Disciplines, All India Institute of Medical Sciences, New Delhi-11029, India

Full list of author information is available at the end of the article
}

cancers and carcinoids. However, the literature on PETCT findings in MECs is scanty. We present three cases of this rare tumor with the FDG uptake patterns, and review the available literature.

\section{Case presentation}

This was an investigative protocol, which was approved by the ethics committee of our institution, and informed consent was gained for each patient.

All patients presenting with tracheal-bronchial tumors underwent ${ }^{18}$ F-FDG PET-CT and ${ }^{68}$ Gallium 1,4,7,10Tetraazacyclododecane- $\mathrm{N}^{\mathrm{I}}, \mathrm{N}^{\mathrm{II}}, \mathrm{N}^{\mathrm{III}}, \mathrm{N}^{\mathrm{IIII}}$,- tetra acetic acid (D) - Phel $^{1}$ - Tyr $^{3}$-octreotide $\left({ }^{8}\right.$ Ga-DOTATOC) PET-CT using a dedicated PET-CT scanner (Biograph 64; Siemens Medical Solutions Inc, Mountain View, CA, USA) 
to assess the diagnostic value of these methods in evaluating bronchial tumors.

We present three such cases, for which the histologic diagnosis was MEC, and retrospectively analyze their PET-CT findings and histopathologic grading. Their clinical parameters and other details are given in Table 1.

\section{Case 1}

A 14-year-old Caucasian girl presented with a one-year history of cough and gradually progressive dyspnea. On clinical examination, decreased air entry was noted on the left side of the chest. Contrast enhanced CT (CECT) of the chest revealed a mass measuring $27 \times 16 \mathrm{~mm}$ and occluding the left main bronchus. On bronchoscopy, the mass was seen to be occluding the left main bronchus. Results of a bronchoscopic biopsy were inconclusive. The patient underwent a ${ }^{18} \mathrm{~F}$-FDG PET-CT scan (Figure 1) which revealed mild uptake in the tumor (maximum standardized uptake value (SUVmax) 4.4), whereas ${ }^{68} \mathrm{Ga}$-DOTATOC PET-CT revealed no significant uptake (Figure 2). The patient underwent a sleeve resection of the tumor, and had an uneventful recovery. Histopathologic examination revealed features of lowgrade MEC.

\section{Case 2}

A 21-year-old Caucasian man presented with a one-year history of cough and dyspnea on exertion. CECT of the chest revealed a $10 \times 10 \mathrm{~mm}$ mass in the right main bronchus. Bronchoscopic examination revealed a mass in the right main bronchus, which bled on contact. ${ }^{18} \mathrm{~F}$ FDG PET-CT revealed slight uptake (SUVmax 3.2) in the tumor, whereas ${ }^{68} \mathrm{Ga}$-DOTATOC PET-CT revealed no significant uptake. Histological results of a biopsy taken from the mass were suggestive of low-grade MEC.

\section{Case 3}

A 24-year-old Caucasian man presented with a one-year history of cough and haemoptysis. On clinical examination, decreased air entry was detected on the right side of the chest. CECT revealed a mass of $35 \times 38 \mathrm{~mm}$ in the right main bronchus with collapse of the right lung. Bronchoscopic examination revealed a mass starting at the level of the carina, occluding the right main bronchus completely. Histopathological examination of a bronchoscopic biopsy of the mass was suggestive of a neuroendocrine tumor. ${ }^{18} \mathrm{~F}$-FDG PET-CT revealed mild uptake in the tumor (SUVmax 3.9), whereas ${ }^{68} \mathrm{Ga}$ DOTATOC PET-CT revealed no significant uptake. The patient underwent a right pneumonectomy with resection of the carina. Histopathologic examination of the operative specimen revealed features of low-grade MEC.

\section{Discussion}

MEC is an uncommon lesion accounting for under $1 \%$ of primary malignant bronchial tumors. Although generally indolent, local invasion and lymph node metastases may occur. The tumor generally affects patients aged over 30 years. Patients usually present with cough, haemoptysis, wheezing and recurrent pneumonia due to bronchial obstruction, but $9 \%$ to $28 \%$ of cases may be asymptomatic $[2,3]$.

Histologically, MECs are composed of varying mixtures of mucus-secreting, columnar and goblet cells. They are classified as high-grade or low-grade based on histologic appearance (number of mitoses, nuclear pleomorphism and necrosis). The histopathologic grading also reflects the prognosis of these tumors [2].

On conventional radiology, MECs usually appear as oval or lobulated, slightly enhanced, endobronchial masses with occasional punctuate calcification. There

Table 1 Patient characteristics and other details

\begin{tabular}{|c|c|c|c|c|c|c|c|c|c|}
\hline $\begin{array}{l}\text { Case } \\
\text { number }\end{array}$ & $\begin{array}{l}\text { Age/ } \\
\text { sex }\end{array}$ & Symptoms & CT findings & Bronchoscopy & $\begin{array}{l}\text { Bronchoscopic } \\
\text { biopsy }\end{array}$ & $\begin{array}{l}\text { FDG PET- } \\
\text { CT scan }\end{array}$ & $\begin{array}{l}\text { DOTATOC } \\
\text { PET-CT } \\
\text { scan }\end{array}$ & $\begin{array}{l}\text { Operative } \\
\text { procedure }\end{array}$ & $\begin{array}{l}\text { Final } \\
\text { diagnosis }\end{array}$ \\
\hline 1 & $14 / \mathrm{F}$ & $\begin{array}{l}\mathrm{C}, \mathrm{D} \times 1 \\
\text { year }\end{array}$ & $\begin{array}{l}27 \times 16 \mathrm{~mm} \text { mass } \\
\text { occluding the left } \\
\text { main bronchus. }\end{array}$ & $\begin{array}{l}\text { Infiltrative growth } \\
\text { occluding the left } \\
\text { main bronchus }\end{array}$ & Inconclusive & $\begin{array}{l}\text { Uptake } \\
\text { positive } \\
\text { (SUVmax } \\
\text { 4.4) (Figure } \\
\text { 1) }\end{array}$ & $\begin{array}{l}\text { No } \\
\text { significant } \\
\text { uptake } \\
\text { (Figure 2) }\end{array}$ & $\begin{array}{l}\text { Sleeve resection } \\
\text { of left main } \\
\text { bronchus }\end{array}$ & $\begin{array}{l}\text { Low- } \\
\text { grade } \\
\text { MEC }\end{array}$ \\
\hline 2 & $\begin{array}{l}21 / \\
M\end{array}$ & $\begin{array}{l}C, D \times 1 \\
\text { year }\end{array}$ & $\begin{array}{l}10 \times 10 \mathrm{~mm} \text { mass } \\
\text { in the right main } \\
\text { bronchus }\end{array}$ & $\begin{array}{l}\text { Polypoidal mass in } \\
\text { the right main } \\
\text { bronchus }\end{array}$ & Low-grade MEC & $\begin{array}{l}\text { Uptake } \\
\text { positive } \\
\text { (SUVmax } \\
\text { 3.2) }\end{array}$ & $\begin{array}{l}\text { No } \\
\text { significant } \\
\text { uptake }\end{array}$ & No surgery yet & $\begin{array}{l}\text { Low- } \\
\text { grade } \\
\text { MEC }\end{array}$ \\
\hline 3 & $\begin{array}{l}24 / \\
M\end{array}$ & $\begin{array}{l}\mathrm{C}, \mathrm{H} \times 1 \\
\text { year }\end{array}$ & $\begin{array}{l}35 \times 38 \mathrm{~mm} \text { mass } \\
\text { in right main } \\
\text { bronchus going } \\
\text { up to the carina }\end{array}$ & $\begin{array}{l}\text { Polypoidal growth } \\
\text { starting at carina } \\
\text { and occluding right } \\
\text { main bronchus }\end{array}$ & $\begin{array}{l}\text { ?Neuroendocrine } \\
\text { tumor }\end{array}$ & $\begin{array}{l}\text { Uptake } \\
\text { positive } \\
\text { (SUVmax } \\
\text { 3.9) }\end{array}$ & $\begin{array}{l}\text { No } \\
\text { significant } \\
\text { uptake }\end{array}$ & $\begin{array}{l}\text { Right } \\
\text { pneumonectomy } \\
\text { with carinal } \\
\text { resection }\end{array}$ & $\begin{array}{l}\text { Low- } \\
\text { grade } \\
\text { MEC }\end{array}$ \\
\hline
\end{tabular}

C- Cough, D- Dyspnea, DOTATOC PET-CT (1,4,7,10-tetraazacyclododecane- $N^{\prime}, N^{\prime \prime}, N^{\prime \prime I}, N^{\prime \prime I I I},-$ tetra acetic acid (D) - Phel ${ }^{1}$-Tyr ${ }^{3}$-octreotide positron emission tomography computed tomography), F- Female, FDG PET-CT- fluorodeoxyglucose positron emission tomography computed tomography, H-Haemoptysis, M- Male, MECmucoepidermoid carcinoma, SUVmax- maximum standardized uptake value. 


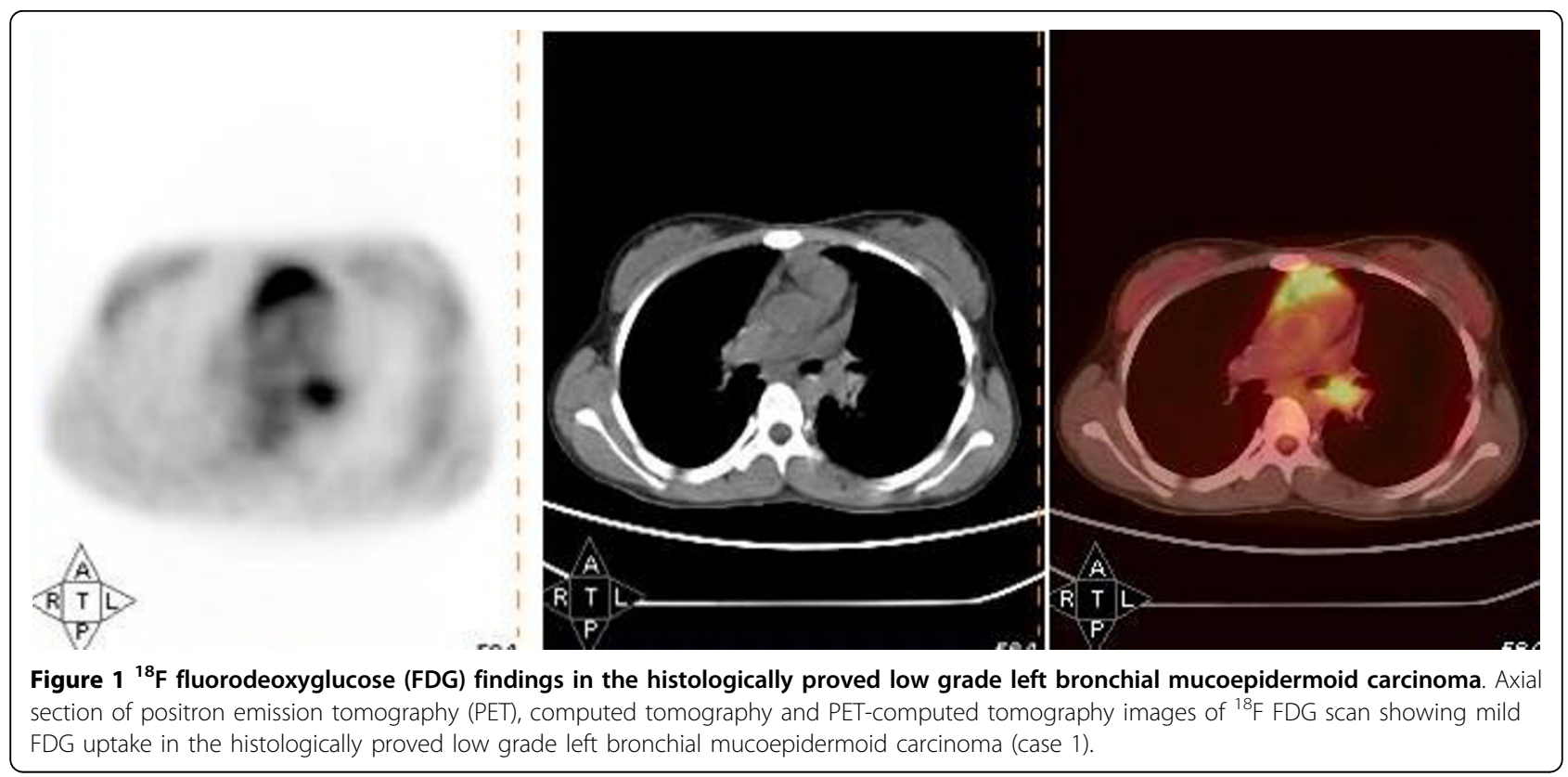

may be post-obstructive pneumonia and/or peripheral atelectasis [3].

Functional imaging is emerging as a helpful tool for the evaluation of bronchopulmonary tumors. However, experience in MECs is limited, with 12 cases reported from six studies (summarized in Table 2) [2-7]. The range of SUVmax values on ${ }^{18}$ F-FDG PET-CT scan varies from zero to 6.2 for low-grade MECS and from 2.86 to 23.4 for high-grade MECs. We found uniformly slight uptake (low SUV) on ${ }^{18} \mathrm{~F}$-FDG PET-CT in all three cases, all of which had a histopathologic diagnosis of low-grade MEC (Figure 1). Thus, our study suggests that the SUVmax on ${ }^{18}$ F-FDG PET-CT scan may be a predictor for histopathologic differentiation of MEC.

Bronchial carcinoids constitute a common differential diagnosis for MECs, both by structural radiology and by ${ }^{18}$ F-FDG PET-CT. In doubtful cases, such as those with an inconclusive preoperative biopsy, a ${ }^{68} \mathrm{Ga}$-DOTATOC PET-CT scan can be performed, results of which are usually positive for typical bronchial carcinoids and negative for MECs (Figure 2) [8].

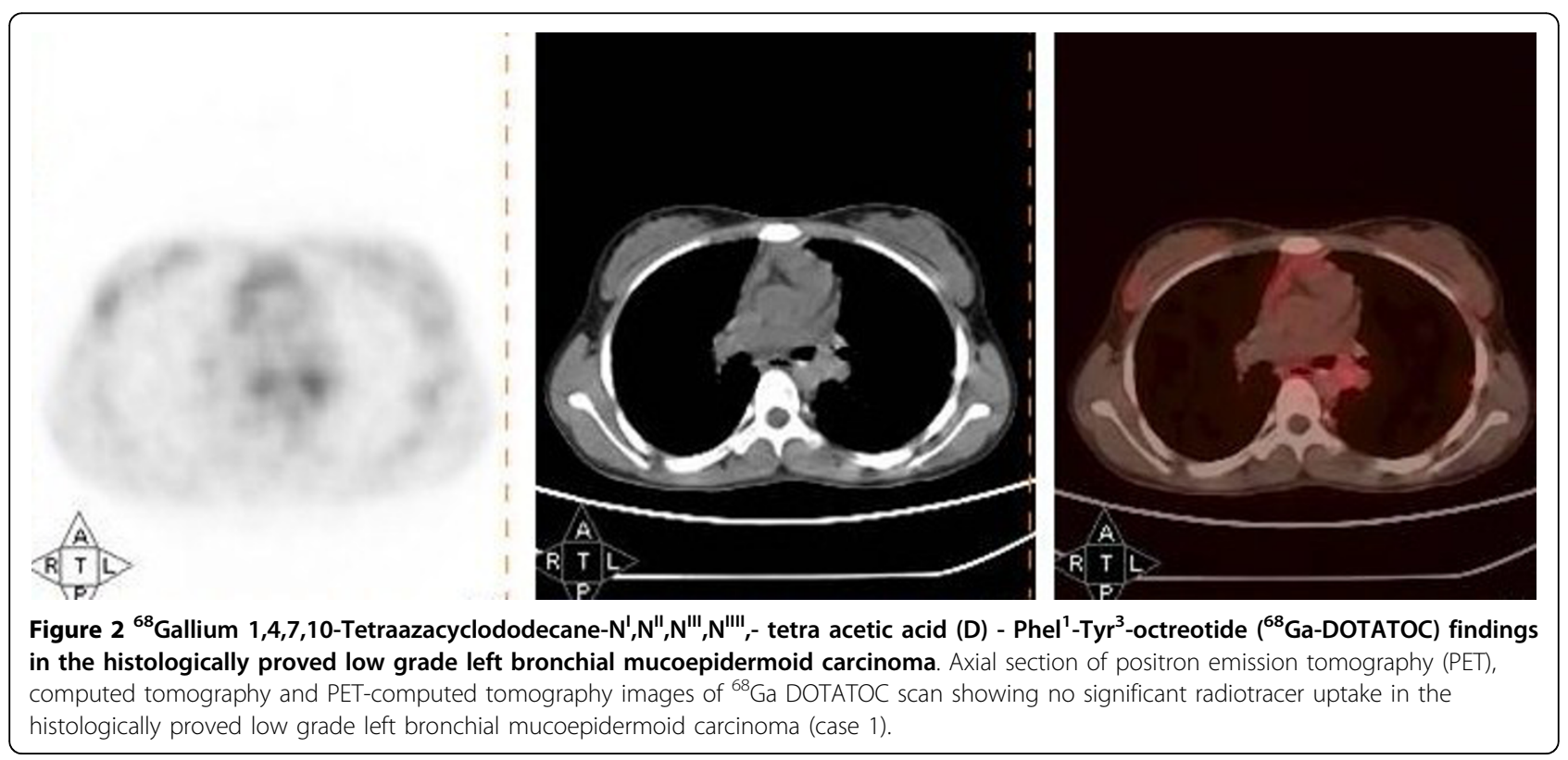


Table 2 Review of the literature of pulmonary mucoepidermoid carcinomas

\begin{tabular}{|c|c|c|c|c|c|c|}
\hline \multirow[t]{2}{*}{ Patient number } & \multirow[t]{2}{*}{ Reference } & \multirow[t]{2}{*}{ Number of cases } & \multicolumn{2}{|c|}{ Grade } & \multicolumn{2}{|c|}{ Range of SUVmax on FDG scan } \\
\hline & & & Low & High & Low grade & High grade \\
\hline 1 & Lee et al. [2] & 1 & 1 & - & 6.2 & - \\
\hline 2 & Jeong et al. [3] & 7 & 4 & 2 & 1.5 to 5.5 & 4.8 to 23.4 \\
\hline 3 & Ishizumi et al. [4] & 1 & 1 & - & 3.63 & - \\
\hline 4 & Kinoshita et al. [5] & 1 & - & - & - & - \\
\hline 5 & Yamada et al. [6] & 1 & - & 1 & - & 2.86 \\
\hline 6 & Shim et al. [7] & 1 & - & - & No uptake & - \\
\hline
\end{tabular}

\section{Conclusion}

Although the overall reported experience is very limited, ${ }^{18}$ F-FDG PET-CT scan might be a useful method for assessing MECs. ${ }^{18} \mathrm{~F}-\mathrm{FDG}$ PET-CT may also have a prognostic relevance by predicting the histopathologic differentiation of the tumor.

\section{Consent}

Written informed consent was obtained from patients two, three and from patient one's father for publication of this case report and accompanying images. A copy of the written consent is available for review by the Editorin-Chief of this journal.

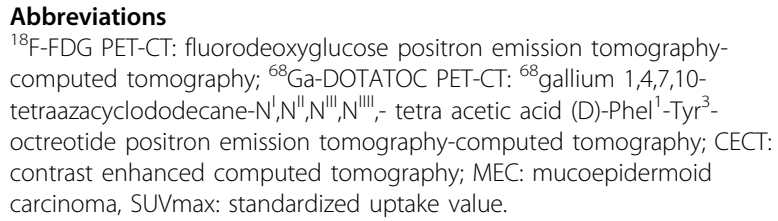

\section{Author details}

'Department of Surgical Disciplines, All India Institute of Medical Sciences, New Delhi-11029, India. ${ }^{2}$ Department of Nuclear Medicine, All India Institute of Medical Sciences, New Delhi-11029, India.

\section{Authors' contributions}

TJ conceived the study and made a major contribution in the compilation, analysis, literature review and formatting of the manuscript, AK had a major contribution in the analysis and editing, RK helped in the study design and data acquisition, RD contributed in data analysis, MM helped in the review of the literature. All the authors have read the final manuscript and have approved it.

\section{Competing interests}

The authors declare that they have no competing interests.

Received: 23 October 2009 Accepted: 19 August 2010 Published: 19 August 2010

\section{References}

1. Colby TV, Koss MN, Travis WD: Tumours of salivary gland type. Tumours of the lower respiratory tract. AFIP Atlas of Tumour Pathology Washington, DC: American Registry of Pathology 1995, 13:65-89, 3rd series.

2. Lee EY, Vargas SO, Sawicki GS, Boyer D, Grant FD, Voss SD: Mucoepidermoid carcinoma of bronchus in a pediatric patient: (18)FFDG PET findings. Pediatr Radiol 2007, 37(12):1278-1282.

3. Jeong SY, Lee KS, Han J, Kim BT, Kim TS, Shim YM, Kim J: Integrated PET/ $\mathrm{CT}$ of salivary gland type carcinoma of the lung in 12 patients. AJR Am J Roentgenol 2007, 189(6):1407-1413.
4. Ishizumi T, Tateishi U, Watanabe S, Maeda T, Arai Y: F-18 FDG PET/CT imaging of low-grade mucoepidermoid carcinoma of the bronchus. Ann Nucl Med 2007, 21(5):299-302.

5. Kinoshita H, Shimotake T, Furukawa T, Deguchi E, Iwai N: Mucoepidermal carcinoma of the lung detected by positron emission tomography in a 5-year-old girl. J Pediatr Surg 2005, 40:E1-3.

6. Yamada T, Chiba W, Yasuba H, Shimada T, Kudo M, Hamada K, Yamashita K, Kita H, Hitomi S: Successful treatment of bronchial mucoepidermoid carcinoma by bronchoplasty. Kyobu Geka 2005, 58:531-536.

7. Shim SS, Lee KS, Kim BT, Choi JY, Chung MJ, Lee EJ: Focal parenchymal lung lesions showing a potential of false-positive and false-negative interpretations on integrated PET/CT. AJR Am J Roentgenol 2006, 186(3):639-648.

8. Gabriel M, Decristoforo C, Kendler D, Dobrozemsky G, Heute D, Uprimny C, Kovacs P, Von Guggenberg E, Bale R, Virgolini IJ: ${ }^{68}$ Ga-DOTA-Tyr ${ }^{3}$ octreotide PET in neuroendocrine tumours: comparison with somatostatin receptor scintigraphy and CT. J Nucl Med 2007, 48(4):508-518.

doi:10.1186/1752-1947-4-277

Cite this article as: Jindal et al:: Role of positron emission tomographycomputed tomography in bronchial mucoepidermoid carcinomas: a case series and review of the literature. Journal of Medical Case Reports $20104: 277$.

\section{Submit your next manuscript to BioMed Central and take full advantage of:}

- Convenient online submission

- Thorough peer review

- No space constraints or color figure charges

- Immediate publication on acceptance

- Inclusion in PubMed, CAS, Scopus and Google Scholar

- Research which is freely available for redistribution 